\title{
Case report: Methotrexate-induced pericardial effusion
}

\author{
Olgu sunumu: Metotreksata bağlı perikardiyal efüzyon \\ Betül Dündar, Alper Karalök, Işın Üreyen, Burcu Gündoğdu, Reyhan Öçalan, Taner Turan, Nurettin Boran, \\ Gökhan Tulunay, M. Faruk Köse \\ Gynecologic Oncology Division, Etlik Zübeyde Hanim Women's Health Research and Teaching Hospital, Ankara, Turkey
}

\section{Abstract}

We report a case of pericardial effusion induced by methotrexate in a patient with low risk gestational trophoblastic neoplasia, who had been taking the first course of sequential methotrexate-folinic acid treatment. After aspiration of pericardial effusion another methotrexate-folinic acid course was given and the pericardial effusion did not relapse. (J Turkish-German Gynecol Assoc 2013; 14: 48-9)

Key words: Methotrexate, toxicity, pericardial effusion, gestational trophoblastic neoplasia, treatment

Received: 07 August, 2012

Accepted: 18 September, 2012

\section{Özet}

Ardışık metotreksat-folinik asit tedavisi verilen düşük riskli gestasyonel trofoblastik neoplazi olgusunda ilk kemoterapi kürü sonrasında perikardiyal efüzyon gelişti. Perikardiyal efüzyon aspire edildikten sonra ikinci kür kemoterapi verildi ve olgumuzda perikardiyal efüzyonun tekrar etmediği gözlendi.

(J Turkish-German Gynecol Assoc 2013; 14: 48-9)

Anahtar kelimeler: Metotreksat, toksisite, perikardiyal efüzyon, gestasyonel trofoblastik neoplazi, tedavi

Geliş Tarihi: 07 Ağustos 2012

Kabul Tarihi: 18 Eylül 2012

\section{Introduction}

In gynecologic oncology methotrexate is an important agent for treatment of gestational trophoblastic neoplasia (GTN). It is used as a single agent in the treatment of low risk GTN and also in high risk GTN as a component of multi-agent chemotherapy. It is possible to provide nearly $100 \%$ survival rates in the case of non-metastatic GTN and in low risk metastatic GTN with single agent methotrexate chemotherapy (1). During methotrexate chemotherapy mucositis and hematological adverse effects are common (2). Also serositis is an important component of methotrexate induced toxicity profile. Serositis usually presents itself as pneumonia and pleural effusion. Pericarditis and pericardial effusion which are also serositis complications are quite uncommon ones.

We report a case of pericardial effusion induced by methotrexate treatment in a patient with low risk GTN.

\section{Case Report}

A 33 year old woman was diagnosed histopathologically as partial hydatidiform mole after evacuation. During the follow up period careful monitoring of the patient revealed levelling of $\beta$-hCG levels, which means gestational trophoblastic neoplasia and the appropriate treatment is planned for the patient.

The $\beta$-hCG level before the treatment was $75 \mathrm{mIU} / \mathrm{mL}$ and there was no tumoral mass revealed by the imaging methods except in the uterus. The tumoral mass in the uterus was $3 \mathrm{~cm}$ in diameter and there were no metastases in the upper abdomen, lungs and brain. According to the modified World Health Organization (WHO) prognostic scoring criteria, the case was a low risk GTN and the treatment plan was sequential methotrexate-folinic acid chemotherapy. On the $1^{\text {st }}, 3^{\text {th }}$, $5^{\text {th }}$ and $7^{\text {th }}$ days of chemotherapy $1 \mathrm{mg} / \mathrm{kg}$ methotrexate was given by intramuscular injection, on the $2^{\text {nd }}, 4^{\text {th }}, 6^{\text {th }}$ and $8^{\text {th }}$ days $0.1 \mathrm{mg} / \mathrm{kg}$ folinic acid was given by intramuscular injection also. After the $\beta$-hCG levels returned to normal ranges, a second cure of methotrexate-folinic acid chemotherapy was planned. Following the first course of methotrexatefolinic acid chemotherapy according to WHO toxicity criteria, grade 2 hepatotoxicity had developed. Before the $2^{\text {nd }}$ cure, because of sinusitis, the patient was given antibiotherapy. In the following time period chest pain and shortness of breath developed and therefore electrocardiography, chest X-ray, thoracic computerized tomography and echocardiography were performed. The echocardiography revealed massive pericardial effusion of $2.8 \mathrm{~cm}$ depth posteriorly and $0.8 \mathrm{~cm}$ depth anteriorly. Meanwhile, the $\beta$-hCG was $4.55 \mathrm{mIU} / \mathrm{mL}$, aspartate aminotransferase (AST) was 52U/L (normal 5-40), alanine aminotransferase (ALT) 88U/l (normal 5-40) and CA 125 was $99.5 \mathrm{IU} / \mathrm{L}$, complete blood count and other biochemical tests were normal. The patient was hospitalized and the pericardial effusion was aspirated. Pericardial fluid was examined microbiologically, cytologically and biochemically, 
which did not reveal any abnormalities explaining pericardial effusion. The second course of methotrexate chemotherapy was given 14 days later than the planned date. Methotrexate induced pericardial effusion did not relapse after the second course of chemotherapy. Three months after the diagnosis of pericardial effusion CA 125 levels returned to normal ranges. In the following twelve months cardiological or oncological problems did not develop.

\section{Discussion}

It is known that serositis is a component of the methotrexate induced toxicity profile. The etiology and pathophysiology is unknown. However it is thought that this process is due to a specific cellular immune response developing against the drug $(3,4)$. Therefore, serositis is not a direct toxic effect of the drug. The serositis commonly presents itself in the form of pneumonitis and pleural effusion. The frequency of methotrexate induced serosal symptoms is $5-12 \%$ with doses used in oncology clinics $(5,6)$. However, in persistent cases where repetitive doses are used, the serosal symptoms reach $20-25 \%(7,8)$. Sharma et al. (8) reported the rate of serosal symptoms as $25 \%$ in 168 patients who received low dose sequential methotrexate-folinic acid treatment. It is thought that the risk of developing serositis increases as the frequency of doses applied increases (9).

Since serositis commonly presents itself in the form of pleurisy in these patients, respiratory system findings and chest pain of varying degrees of severity are prominent. However it is possible to observe findings of peritonitis and pericarditis according to the site of serosal involvement. Generally, symptoms are easily controlled by analgesia, but in $12 \%$ of patients symptoms may be severe enough to, cause some variations in the treatment $(8,10)$

Methotrexate induced pericardial effusion and pericarditis was first reported by Forbat et al. (10) The case was a 22 year old low risk GTN, receiving methotrexate chemotherapy. The patient tolerated methotrexate chemotherapy well until the seventh cure. During the seventh cure minimal pleuritic chest pain on the left side had developed and by auscultation a pleural friction sound was heard. Because of these findings the diagnosis was methotrexate induced pleurisy. The patient in this case responded to analgesic treatment rapidly and the methotrexate chemotherapy was continued until the ninth cure was completed. Two months after chemotherapy the patient developed chest pain again and also dyspnea induced by exercise. Chest X-ray and echocardiography revealed a large pericardial effusion of $5 \mathrm{~cm}$ depth posteriorly and $2 \mathrm{~cm}$ depth anteriorly. The electrocardiography and routine blood tests were normal and the clinical findings became normal after aspiration of $650 \mathrm{cc}$ pericardial fluid. The aspirated fluid was in the form of inflammatory exudate and the tests for viral and bacterial agents, including tuberculosis, and cytology were negative. It was observed that in the follow up of the patient serositis did not develop.

Although peritonitis is an infrequent type of serositis, it was first reported by Sharma et al. (8) in 1999. The reported case was a 27 year old patient receiving methotrexate chemotherapy for persistent GTN. The patient developed relapsing peritonitis after each methotrexate course. This clinical finding was thought to be methotrexate induced and the treatment protocol was changed. During the clinical follow up of this patient, symptoms of peritonitis did not recur.

It is thought that in the case of methotrexate induced peritonitis, it is not necessary to interupt the treatment since it does not increase the relapses (8). However it is equivocal for very infrequent cases of pericarditis and peritonitis. In the case we reported, after the cardiologic consultation and intervention we continued methotrexate chemotherapy. In the following cure cardiac symptoms did not recur.

Serositis induced by methotrexate is very common, but pericarditis and pericardial effusion are very infrequent adverse effects of the drug. Although pericardial effusion is a result of methotrexate chemotherapy we kept on giving methotrexate until remission was provided in this case. At the end we observed that a further attack of pericardial effusion did not occur. On the other hand, there is no consensus about the safety of the use of methotrexate after an episode of serositis. Other treatment modalities could be considered for these patients.

\section{Conflict of interest}

No conflict of interest was declared by the authors.

\section{References}

1. Lurain JR, Elfstrand EP. Single-agent methotrexate chemotherapy for the treatment of nonmetastatic gestational trophoblastic tumors. Am J Obstet Gynecol 1995; 172: 574-9. [CrossRef]

2. Berkowitz RS, Goldstein DP, Bernstein MR. Ten year's experience with methotrexate and folinic acid as primary therapy for gestational trophoblastic disease. Gynecol Oncol 1986; 23: 111-8. [CrossRef]

3. Akoun GM, Gauthier-Rahman S, Mayaud CM, Touboul JL, Denis MF. Leukocyte migration inhibition in methotrexate-induced pneumonitis. Evidence for an immunologic cell-mediated mechanism. Chest 1987; 91: 96-9. [CrossRef]

4. White DA, Rankin JA, Stover DE, Gellene RA, Gupta S. Methotrexate pneumonitis. Bronchoalveolar lavage findings suggest an immunologic disorder. Am Rev Respir Dis 1989; 139: 18-21. [CrossRef]

5. Massin F, Coudert B, Marot JP, Foucher P, Camus P, Jeannin L. Pneumopathy caused by methotrexate. Rev Mol Respir 1990; 7: 5-15.

6. Stover D. Adverse effect of treatment pulmonary toxicity. In: Cancer Principle and Practice of Oncology. 4th ed, DeVilla S, Hellman S, Rosenberg S (eds), pp:2362-2365, JB Lippincott, Philadelphia

7. Sheridan E, Hancock BW, Smith SC, Dorreen MS, Neal FE, Pennington G, et al. Gestational trophoblastic disease - experience of the sheffield (United-kingdom) supraregional screening and treatment service. Int J Oncol 1993; 3: 149-55.

8. Sharma S, Jagdev S, Coleman RE, Hancock BW, Lorigan PC. Serosal complications of single-agent low-dose methotrexate used in gestational Trophoblastic diseases: First reported case of methotrexateinduced peritonitis. Br J Cancer 1999; 81: 1037-41. [CrossRef]

9. Ginsberg SJ, Comis RL. The pulmonary toxicity of antineoplastic agents. Semin Oncol 1982; 9: 34-51.

10. Forbat LN, Hancock BW, Gershlick AH. Methotrexate-induced pericarditis and pericardial effusion; first reported case. Postgrad Med J 1995; 71: 244-5. [CrossRef] 